\title{
PEMBELAJARAN KONTEKSTUAL DALAM MEMBANGKITKAN KEPEMIMPINAN TRANSFORMATIF
}

\author{
Nur Wahyu Eko Pramono
}

MTsN 2 Mejobo Kudus, Jawa Tengah Indonesia nurwahyueko@yahoo.com

\begin{abstract}
THE CONTEXTUAL TEACHING IN RAISE TRANSFORMATIVE LEADERS. The aim of this writing article is to discuss about the role in mathematics teaching contextual in raising transformative leadership and creativity thinking students. This was done because some students are still regarded as mathematical knowledge thatonly focused on ability to think logically and the settlement was a single and be sure. They also viewed that mathematics is aboring, frightening, and most difficult than other subjects. Mathematics material is lack in able to apply in daily life. In fact, every levels of education, mathematics lessons is learned and become one of the indicator in taking levels of education students' success. These problems arise because mathematics can only be considered as a tool and symbols, not as a basis for the thinking leadership who eventually can affect a person's perspective in solving problems of life. Through the action research class (PTK), by taking sample random in grade IXat MTs $N$ IIKudus 32 students, in conclude that learning mathematics contextual really help teachers in tie between learning materials to the real world situation, and encourage the students more active to thinking creatively in solving various problems. Johnson (2006) which said that contextual learning system is a procedure education that could belp the students in seeing the meaning in every teaching materials with how to be joined with their daily lives context.
\end{abstract}

Keyword : Contextual,Teaching, Transformative 


\begin{abstract}
Abstrak
Tujuan penulisan artikel ini adalah membahas tentang peran pembelajaran matematika konstekstual dalam membangkitkan kepemimpinan transformative dan kreatifitas berfikir siswa. Hal ini dilakukan karena beberapa siswa masih menganggap matematika sebagai ilmu yang hanya menekankan pada kemampuan berpikir logis saja dengan penyelesaian yang tunggal dan pasti. Mereka juga menganggap bahwa pelajaran matematika adalab pelajaran yang paling sulit dibandingkan mata pelajaran lainnya, membosankan, dan menakutkan. Materi dalam pelajaran matematika kurang bisa diaplikasikan dalam kehidupan sehari-hari. Padahal, disetiap jenjang pendidikan, matematika dipelajari dan menjadi salah satu indikator keberhasilan siswa dalam menempuh jenjang pendidikan. Masalah tersebut muncul karena matematika hanya dianggap sebagai alat dan simbol, bukan sebagai dasar dalam kepemimpinan berfikir yang nantinya bisa mempengarubi cara pandang seseorang dalam menyelesaikan berbagai problem kehidupan. Melalui proses Penelitian Tindakan Kelas (PTK), dengan mengambil sampel secara random pada siswa kelas IX di MTs N II Kudus sebanyak 32 siswa, di simpulkan bahwa pembelajaran matematika kontekstual sangat membantu guru dalam mengkaitkan antara materi pembelajaran dengan situasi dunia nyata, dan mendorong siswa semakin aktif berfikir kereatif dalam menyelesaikan berbagai masalabnya. Hal ini mendukung teori Johnson (2006) yang menyatakan bahwa sistem pembelajaran konstektual merupakan suatu prosedur pendidikan yang bisa membantu siswa dalam melihat makna pada setiap bahan pelajaran dengan cara menghubungkannya dengan konsteks kehidupan mereka sehari-hari.
\end{abstract}

Keyword: Pembelajaran, Konstekstual, Transformatif, Kreatif

\title{
A. Pendahuluan
}

Peraturan Menteri Pendidikan Nasional Nomor 22 Tahun 2006 tanggal 23 Mei 2006 tentang standar isi pelajaran matematika untuk satuan pendidikan dasar dan menengah telah disebutkan bahwa mata pelajaran matematika perlu diberikan pada semua peserta didik mulai dari sekolah dasar hingga sekolah menengah tingkat atas untuk membekali peserta didik dengan kemampuan berpikir logis, analitis, sistematis, kritis, dan kreatif, 
serta kemampuan bekerjasama dengan baik. Hal ini telah lama menjadi fokus dan perhatian para pendidik matematika, karena sangat terkait dengan sifat dan karakteristik keilmuan matematika. Tetapi secara empiris, fokus dan perhatian pada upaya peningkatan kemampuan berpikir kreatif siswa berbasis matematika masih belum banyak dikembangkan. Padahal hal tersebut sangat dibutuhkan agar peserta didik memiliki jiwa dan kepemimpinan transformative, memiliki kemampuan mencari, mengelola, dan memanfaatkan informasi untuk bertahan hidup dalam kondisi yang selalu berubah, tidak pasti dan sangat kompetitif dalam era globalisasi seperti sekarang ini.

Tantangan masa depan, terutama dalam menghadapi persaingan di era global yang semakin ketat membutuhkan output pendidikan yang tidak hanya terampil dalam satu bidang tetapi juga kreatif dalam mengembangkan bidang yang lain. Hal tersebut perlu dimanifestasikan dalam setiap mata pelajaran di sekolah, tak terkecuali pelajaran matematika. Tugas Guru matematika dalam menyampaikan materinya tidak hanya sekedar teori dan itungitungan belaka, tetapi juga membekali siswa dengan berbagai aplikasinya dalam kehidupan nyata. Tujuannya, pertama adalah agar siswa memahami bahwa apa yang dipelajari merupakan bekal dan berguna dalam kehidupan. Kedua, agar siswa mudah mengerti materi pembelajaran dan bisa menjadi memori jangka panjang. ${ }^{1}$

Guru juga harus menjelaskan bahwa lahirnya subsub bagian dalam pelajaran matematika yang terdiri dari Aritmatika, Aljabar dan Geometri merupakan salah satu bentuk manifestasi dari berbagai kejadian dan kebutuhan manusia sehari-hari. Sebagaimana aritmatika sosial sangat dibutuhkan untuk menghitung untung rugi dalam bisnis dan perdagangan. Aljabar sangat dibutuhkan untuk menentukan kapasitas atau daya tampung dari suatu bidang/bangun ruang. Geometri sangat

\footnotetext{
${ }^{1}$ Siswono, Tatag Yuli Eko, Upaya Meningkatkan Kemampuan Berpikir Kreatif Siswa Melalui Pengajuan Masalab dalam Jurnal Pendidikan Matematika dan Sains, FMIPA Universitas Negeri Yogyakarta. Tahun X, No. 1, Juni 2005, hlm 23-26.
} 
dibutuhkan militer pada saat menentukan letak suatu obyek/ tempat sasaran tembak dan lain-lain.

Tetapi, faktanya tidak banyak siswa yang menyukai pelajaran matematika dan memahaminya dengan baik dan ideal. Matematika dianggap pelajaran paling sulit dan hanya sebagai ilmu yang menekankan pada kemampuan berpikir logis dengan penyelesaian yang tunggal dan pasti. Padahal, matematika dipelajari pada setiap jenjang pendidikan dan menjadi salah satu pengukur (indikator) keberhasilan siswa dalam menempuh jenjang pendidikan, serta menjadi materi ujian untuk seleksi penerimaan menjadi tenaga kerja bidang tertentu. Oleh karena itu, tulisan ini memaparkan tentang peran salah satu proses pembelajaran ideal yaitu kontekstual yang bisa digunakan guru matematika dalam transfer ilmu sehingga bisa menghasilkan kepemimpinan transformatif dan kreatifitas berpikir pada siswa.

\section{B. Pembahasan}

\section{Pembelajaran Kontekstual}

Pembelajaran kontekstual atau yang disebut dengan Contextual Teaching and Learning (CTL) adalah konsep belajar yang membantu guru mengaitkan antara materi pembelajaran dengan situasi dunia nyata siswa, dan mendorong siswa membentuk hubungan antara pengetahuan yang dimilikinya dengan penerapan kehidupan mereka sehari-hari. Pengetahuan dan ketrampilan siswa diperoleh dari usaha siswa menghubungkan dan mengkonstruksi sendiri pengetahuan dan ketrampilan baru ketika ia belajar. ${ }^{2}$

Sedangkan Johnson merumuskan pengertian pembelajaran kontekstual adalah sistem prosedur pendidikan yang bertujuan membantu siswa melihat makna dalam bahan pelajaran yang mereka pelajari dengan cara menghubungkannya dengan konteks kehidupan mereka sehari-hari yaitu dengan konteks lingkungan

${ }^{2}$ Depdiknas, Manajemen Peningkatan Mutu Berbasis Sekolab: Pembelajaran dan Pengajaran Konstektual (Jakarta: Dikdasmen, 2002), hlm. 5-7. 
pribadinya, sosial dan budayanya. ${ }^{3}$ Wina Sanjaya mengemukakan bahwa strategi pembelajaran kontekstual adalah suatu strategi pembelajaran yang menekankan kepada proses keterlibatan siswa secara penuh untuk dapat menemukan materi yang dipelajari dan menghubungkannya dengan situasi kehidupan nyata sehingga mendorong siswa dapat menerapkannya dalam kehidupan mereka. Istilah lain pembelajaran kontekstual yaitu" Experiental Learning, Real World Education, Active Learning and Learner Centered. ${ }^{4}$

Secara filosofis, pembelajaran kontekstual banyak dipengaruhi oleh filsafat konstruktivisme yang digagas Mark Baldwin dan selanjutnya dikembangkan oleh Jean Piaget. Piaget berpendapat, bahwa sejak kecil setiap anak sudah memiliki struktur kognitif yang dinamakan "skema". Skema terbentuk karena adanya pengalaman dan secara terus menerus disempurnakan dalam proses asimilasi. Semakin besar pertumbuhan anak maka skema akan semakin sempurna yang kemudian disebut dengan proses akomodasi. Pendapat Piaget tentang bagaimana sebenarnya pengetahuan itu terbentuk dalam struktur kognitif anak, sangat dipengaruhi oleh model pembelajarannya. Diantaranya adalah model pembelajaran kontekstual yang dipercaya mampu membuat pengetahuan menjadi lebih bermakna ketika ditemukan dan dibangun sendiri oleh siswa. Selanjutnya ia mengemukaakan bahwa secara garis besar strategi pembelajaran kontekstual meliputi delapan komponen, yaitu:

a. Membuat keterkaitan-keterkaitan yang bermakna;

b. Melakukan pekerjaan yang berarti;

c. Melakukan pembelajaran yang diatur sendiri;

d. Melakukan kerjasama;

e. Berpikir kritis dan kreatif;

${ }^{3}$ B. Johnson, Elaine, Contextual Teaching dan Learning, Terj, Ibnu Setiawan (Bandung: MLC, 2006), hlm. 43.

${ }^{4}$ Wina Sanjaya, Pembelajaran dalam Implementasi Kurikulum Berbasis Kompetensi (Jakarta : Kencana, 2008), hlm. 120. 
f. Membantu individu untuk tumbuh dan berkembang;

g. Mencapai standar yang tinggi;

h. Menggunakan penilaian autentik. ${ }^{5}$

Selanjutnya dia juga menyebutkan bahwa pembelajaran kontekstual mempunyai beberapa karakteristik sebagai berikut:

a. Activing knowledge, artinya apa yang akan dipelajari tidak terlepas dari pengetahuan yang sudah dipelajari, dengan demikian pengetahuan yang akan diperoleh siswa adalah pengetahuan yang utuh yag memiliki keterkaitan satu sama lain;

b. Acquiring knowledge, artinya pembelajaran dimulai dengan mempelajari secara keseluruhan, kemudian memperhatikan detailnya;

c. Understanding knowledge, artinya pengetahuan yang diperoleh bukan untuk dihafal tetapi untuk dipahami dan diyakini;

d. Applying knowledge, artinya pengetahuan dan pengalaman yang diperolehnya harus dapat diaplikasikan dalam kehidupan siswa, sehingga tampak perubahan perilaku siswa;

e. Reflecting knowledge, hal ini dilakukan sebagai umpan balik untuk proses perbaikan dan penyempurnaan strategi.

Dalam strategi pembelajaran kontekstual, guru tiadak menyampaikan informasi begitu saja, akan tetapi memancing agar siswa dapat menemukan sendiri masalahnya melalui pertanyaanpertanyaan yang dibuat. Dalam hal ini guru harus mampu mengembangkan teknik-teknik bertanya. Selain itu agar hasil maksimal maka lebih mudah dengan membentuk kerjasama antar individu maupun kelompok belajar baik dalam bentuk formal maupun informal. Dengan kerjasama, maka setiap siswa bisa aktif terlibat dan saling bertukar informasi maupu pengalaman.

Pembelajaran kontekstual penting diterapkan dalam kegiatan pembelajaran karena mempunyai beberapa kelebihan

${ }^{5}$ Wina Sanjaya, Pembelajaran dalam Implementasi Kurikulum, hlm. 120. 
yang dapat di tunjukkan dan manfaat yang dirasakan oleh guru dan siswa antara lain:

a) Peserta didik dapat:

1. Mengkaitkan antara mata pelajaran dengan pekerjaan atau kehidupan

2. Mengkaitkan kandungan mata pelajaran dengan pengalaman sehari-hari

3. Memindahkan kemahiran

4. Member kesan dan mendapatkan bukti

5. Menguasai permasalahan abstrak melalui pengalaman kongkrit

6. Belajar secara bersama

b) Pendidik dapat:

1. Menjadikan pengajaran sebagai salah satu pengalaman yang bermakna

2. Mengkaitkan prinsip-prinsip mata pelajaran dengan dunia pekerjaan

3. Menjadikan penghubung antara pihak akademik dan vocational atau industry

Faktor-faktor yang mempengaruhi keberhasilan pembelajaran kontekstual menurut The Northwesh Regional Education Laboratory USA mengidentifikasikan terdapat enam hal yang dapat mempengaruhi keberhasilan pembelajaran kontekstual antara lain:

1. Pembelajaran bermakna yaitu pemahaman relevansi dan penilaian pribadi sangat terkait dengan kepentingan siswa dalam mempelajari materi pelajaran

2. Penerapan pengetahuan yaitu kemampuan siswa untuk memahami apa yang dipelajari dan diterapkan dalam tatanan kehidupan dan fungsi di masa sekarang atau di masa yang akan datang 
3. Berfikir tingkat tinggi: siswa di wajibkan untuk berfikir kritis dan kreatif dalam mengumpulkan data, pemahaman suatu issue dan pemecahan suatu masalah.

4. Kurikulum yang dikembangkan berdasarkan standar yaitu isi pembelajaran harus dikaitkan dengan standar lokal, provinsi, nasional, perkembangan IPTEK serta dunia kerja.

5. Responsive terhadap budaya yaitu guru harus memahami dan menghargai nilai, kepercayaan, dan kebiasaan siswa, teman pendidik dan masyarakat tempat ia mendidik.

6. Penilaian otentik yaitu penggunaan berbagai strategi penilaian (missal: penilaian proyek/tugas terstruktur, kegiatan siswa, penggunaan portofolio, rubric, daftar chek, pedoman observasi) yang akan merefleksikan hasil belajar sesungguhnya

Tujuh komponen penting dalam pembelajaran konstekstual dapat diaplikasikan sebagai berikut:

1. Konstruktivisme

2. Menemukan

3. Bertanya

4. Masyarakat belajar

5. Pemodelan

6. Refleksi

7. Penilaian yang sebenarnya

\section{Kepemimpinan Sebagai Sunnatullah}

Kepemimpinan (memimpin dan dipimpin) menjadi fitrah manusia dan bersifat sunnatullah. Fungsi kepemimpinan yang paling penting adalah sebagai problem solver dalam kehidupan individu dan sosial. Widjayakusuma menyebutkan bahwa unsur kepemimpinan yang diamanatkan kepada seorang pemimpin meliputi:
a. Tanggung jawab (masuliyah);
b. Kewenangan (shalahiyah);
c. Hak pengambilan keputusan (taqrir). 
Sedangkan cakupan kepemimpinan terdiri dari:

a. Kepemimpinan atas diri sendiri,

b. Kepemimpinan dalam komunitas,

c. Kepemimpinan Ide (ideologis). ${ }^{6}$

Dalam Hadist Riwayat. Bukhori, Muslim, Ahmad, Abu Dawud, Tirmidzi dari Ibnu Umar diakatakan bahwa setiap kamu adalah pemimpin dan setiap pemimpin bertanggung jawab atas kepemimpinannya. Setiap kepala negara adalah pemimpin dan ia bertanggung jawab atas kepemimpinannya (rakyat). Seorang perempuan/ibu adalah pemimpin dalam rumah tangga suaminya dan anak-anaknya; ia bertanggung atas kepemimpinannya. Seorang pelayan/hamba sahaya adalah pemimpin atas harta tuannya dan ia bertanggung jawab atas kepemimpinannya. Ketahuilah bahwa setiap kamu adalah pemimpin dan masingmasing mempertanggungjawabkan atas kepemimpinannya." (HR Bukhori, Muslim, Ahmad, Abu Dawud, Tirmidzi dari Ibnu Umar).

Dalam kehidupan manusia terdapat tiga jenis kebutuhan pokok yang melekat pada diri manusia atau bisa disebut sebagai "thoqotul hayawiyah" yaitu meliputi:

a. Kebutuhan jasmani (hajatu al udhawiyah);

b. Naluri (gharizah)

c. Akal $(a q)^{7}$

Untuk menyelesaikan berbagai masalah yang di timbulkan dari tiga kebutuhan tersebut, maka manusia harus memiliki kepemimpinan berfikir, yaitu senantiasa memimpin pola pikir (aqliyah) dan pola sikap (nafsiyah) pribadi agar dalam pemenuhan dan penyaluran kebutuhan pokok dan nalurinya senantiasa sesuai dan dapat dipertanggunggjawabkan kepada sang Khaliq. Seseorang yang mempunyai kepemimpinan berfikir akan mengutamakan dan

${ }^{6}$ Widjayakusuma, Muh Karebet, Menuju Kepemimpinan Penuh Berkah, dalam Materi Presentasi, 2010, hlm. 4-7.

${ }^{7}$ Widjayakusuma, Muh Karebet, Meniju Kepemimpinan Penuh Berkah, dalam Materi Presentasi, 2010, hlm. 4-7. 
menjadikan nilai-nilai agama Islam sebagai aturan dan pedoman dalam hidupnya diatas nilai-nilai yang lain.

Sedangkan ketika seorang siswa berinteraksi dengan individu yang lain maka yang harus diperhatikan adalah siswa harus memiliki kepemimpinan berfikir dalam komunitas. Yang memiliki ide, perasaan dan peraturan (3 in 1) yang sama untuk mencapai suatu tujuan. Dalam hal ini harus ada pengerahan dan pemberdayaan segenap komponen komunitas agar secara bersama-sama dapat mencapai tujuan yang ditetapkan dan interaksi antar individunya berada dalam koridor ide, perasaan dan aturan yang sama yang berasal dari Al-Kholiq.

\section{Kepemimpinan Transformatif}

Kata "transformasi" dalam Ensiklopedia Matematika adalah pemindahan suatu obyek melalui empat metode yaitu:
a. Pergeseran (Translasi)
b. Pencerminan (Refleksi)
c. Perputaran (Rotasi)
d. Perkalian (Dilatasi) $)^{8}$

Arti transformasi bisa dijelaskan dengan contoh sebagai berikut: Bangun A' adalah bayangan dari bangun A dengan sumbu pencerminan y. pencerminan oleh sumbu y disebut juga transformasi y. jika suatu bangun digeser sejauh $3 \mathrm{~cm}$ maka gerak geser ini disebut juga transformasi. Ada dua macam transformasi yaitu:

a. Transformasi isometri

b. Transformasi dilatasi

Transformasi isometri adalah transformasi yang tidak mengubah bentuk, misalnya: pergeseran (translasi), pencerminan (refleksi), pemutaran (rotasi). Sedangkan transformasi perkalian (dilatasi) adalah transformasi yang mengubah bentuk.

${ }^{8}$ Negoro, ST dan Harahap, B, Ensiklopedia Matematika (Jakarta: Ghalia Indonesia, 1999), hlm. 24. 
Proses transformasi yang terdiri dari 4 metode tersebut bisa kita gunakan dalam mengasah kecepatan berfikir seseorang (siswa). Kecepatan berfikir adalah kecepatan dalam memberikan justifikasi atas suatu fakta, yang didasarkan pada pemahaman (idrak) yang sangat cepat. Dengan kemampuan berfikir cepat, maka seseorang akan dengan mudah dan tepat dalam melihat fenomena dan menyelesaikan masalah yang ada. Selain kecepatan berfikir, seorang siswa juga harus berfikir kreatif. Proses transformasi dilatasi ideal dari teks matematik mampu memberikan strimulasi kreatif pada otak manusia sehingga hidupnya tidak monoton, mampu keluar dari kondisi statis dan menjadi turbulence.

Seseorang dikatakan memiliki kepemimpinan transformatif, apabila dia memiliki kesiapan mental, kecepatan berfikir dan berfikir kreatif. Tiga hal tersebut yang secara ideal harus dipunyai seseorang (siswa) ketika mampu melakukan proses transformasi teks matematik dalam pola berfikirnya melalui pembelajaran kontekstual. Hal ini akan menghasilkan pemahaman yang termanifestasikan dalam pola sikap dan perbuatannya. Misal ketika siswa mengahadapi masalah tidak bisa bayar SPP karena orang tuanya tidak mampu secara ekonomi, padahal tuntutan sekolah harus segera memenuhinya, maka langkah dan keputusan apa yang akan dilakukan siswa sangat tergantung dari kepemimpinan berfikirnya. Siswa yang memiliki kepemimpinan berfikir bagus akan segera menyelesaikan masalahnya dengan cara mencari penyebab utama ketidakmampuan orang tua dan mencari solusi tepat dari beberapa solusi alternative terbaik dengan tidak melanggar ketentuan agama dan dia tetap bisa membayar SPP sekolah. Tetapi siswa yang tidak memiliki kepemimpinan berfikir yang bagus, maka akan cenderung cepat menyerah, tanpa solusi yang benar dan bahkan bisa jadi akan keluar dari sekolah.

\section{Kepemimpinan Transformatif dalam Perspektif Sains dan Matematika}

Kebenaran sains dan matematika bersifat waqi'iy. Nilainya bisa benar dan bisa salah tergantung pada kecermatan pengamatan 
dan kepintaran dalam memformulasikan kata-kata maupun lambang-lambang. Karena kebenaran sains dan matematika hanya mengandalkan pengamatan, maka lebih bersifat universal. Siapa pun dapat mengetahui dan membuktikannya. Tetapi di satu sisi kebenaran sains ini dapat berbenturan dengan kebenaran I'tiqadi dan kebenaran syariy. Ketika rumusan dalam sains dan matematika bertentangan dengan aqidah dan syariah, maka rumusan itu harus dinyatakan salah. Karena sains dan matematika hanya merupakan tools atau alat dalam rangka optimalisasi, stimulasi, efisiensi dan efektifitas berfikir manusia. Maka dalam setiap pola kepemimpinan individu yang berbasis pada sains dan matematika harus tetap bertauhid (berlandaskan kebenaran I'tiqadi dan syar'iy) dan bernuansa relijius (memuat kebenaran waqi'iy).

sebenarnya banyak sekali definisi tentang kepemimpinan, namun demikian semua definisi yang ada pada umunya mempunyai unsur yang sama. Kepemimpinan yang efektif adalah kepemimpinan yang mampu menggugah jiwa orang yang dipimpin (followers) untuk mencapai kinerja yang memuaskan. Kepemimpinan harus memiliki unsur-unsur sebagai berikut':

a. Kejujuran terhadap diri sendiri (integrity),

b. Sikap pertanggungjawaban yang tulus (compassion),

c. Pengetahuan (cognizance),

d. Keberanian bertindak sesuai dengan keyakinan (commitment),

e. Kepercayaan pada diri sendiri dan orang lain (confidence)

f. Kemampuan untuk meyakinkan orang lain dalam membangun organisasi (communication).

Menurut Bass \& Avolio ada empat dimensi kepemimpinan transformatif meliputi:

a. Perilaku pemimpin yang membuat pengikut kagum, hormat \& percaya (Idealized Influence)

${ }^{9}$ Stogdill, R. M, Handbook of Leadership (New York: The Free Press, 1974), hlm. 13. 
b. Pemimpin mampu meng-artikulasi harapan pengikut, komit terhadap tujuan \& mampu gugah spirit tim melalui penumbuhan entusiasme \& optimisme (Inspirational motivation)

c. Pemimpin mampu tumbuhkan ide baru, beri solusi kreatif \& motivasi pada pengikut untuk cari pendekatan yang baru dalam pelaksanaan tugas (Intellectual stimulation)

d. Pemimpin mau dengarkan masukan pengikut \& perhatikan kebutuhan pengikut akan pengembangan karir. ${ }^{10}$

Ke-empat hal tersebut diatas merupakan Breakthrough leadership yaitu pemimpin yang mampu membawa perubahan yang mendasar dan besar dalam kehidupan para pengikutnya karena memiliki pemikiran metanoiac (meta = perubahan, nous) noos $=$ pikiran; Yunani). Model kepemimpinan sebagaimana tersebut diatas dinilai sangat tepat karena mampu secara terusmenerus meningkatkan efisiensi, produktivitas dan inovasi guna meningkatkan daya saing organisasi dalam dunia yang makin kompetitif.

Sedangkan syarat-syarat kepemimpinan menurut Kotter Covey meliputi:

a. Berpandangan global;

b. Memiliki nilai-nilai pribadi;

c. Bermotivasi tinggi,;

d. Memiliki pengetahuan mengenai industry dan organisasi;

e. Mampu menjalin relasi yang sangat kuat;

f. Memiliki kemampuan dan keahlian;

g. Memiliki reputasi dan catatan rekor yang bagus. ${ }^{11}$

Sedangkan harmoni sains dan tsaqofah Islam dalam rangka menuju kepemimpinan transformasional dan Islami dari ranah individu terdiri dari:

${ }^{10}$ Bass, B.M. dan Avolio, B. J, Improving Organizational Effectiveness Through Transformational Leadership (Thousand Oaks, CA: Sage, 1994), hlm. 15-18.

${ }^{11}$ Kotter, J, A force for change: How leadership differs from management $(\mathrm{New}$ York Press.,1990), hlm. 32. 
a. Mengenali potensi (ubah paradigm, pahami hakikat diri dan terima dan syukuri diri);

b. Lejitkan kompetensi (analisa SWOT, tingkatkan diri dan kembangkan diri);

c. Matangkan emosi (muhasabah diri, kendalikan diri dan matangkan emosi).

Sedangkan dari ranah organisasi terdiri dari:

a. Analisis lingkungan;

b. Formulasi strategi;

c. Implementasi strategi;

Pengendalian strategi. ${ }^{12}$

Kepemimpinan transformatif sangat bertumpu pada aspek karismastik, visi dan kepemimpinan inspirasi. Bass dan Avolio, merupakan orang yang pertama memperkenalkan Konsep kepemimpinan transformatif dengan mengambil jarak perbedaan antara kepemimpinan transformatif dengan kepemimpinan transaksi. Kepemimpinan transformatif merujuk kepada proses dimana pemimpin berusaha mempengaruhi bawahan dalam meningkatkan motivasi dan kesetiaan mereka terhadap organisasi. ${ }^{13}$ Sedangkan kepemimpinan transaksi bertumpu pada pertukaran manfaat antara pemimpin dan bawahan. Di dalam kepemimpinan ini, pemimpin akan memberi reward kepada bawahan berdasarkan pada prestasi dalam mencapai tujuan organisasi dan memberikan hukuman pada setiap kesalahan dan kegagalan yang dilakukan bawahan. ${ }^{14}$ Pada dasarnya, Burns melihat kepemimpinan transformatif dan kepemimpinan

\footnotetext{
${ }^{12}$ Setiap tahun terdapat berbagai teori yang membahas berbagai aspek kepemimpinan dan dampaknya terhadap keberlangsungan sebuah organisasi (Bryman, 1992), teori kontingensi (Fiedler dan Gracia, 1987), teori path-goal (House, 1976) dan teori kepemimpinan transformasional (Burns, 1978; Bass, 1985). Kebanyakan teori-teori ini berdasarkan pada elemen yang hampir sama yaitu berfokus pada aspek-aspek kepemimpinan yang dapat mempengaruhi keberlangsungan organisasi..

${ }^{13}$ Burns, J.M, Leadership (New York: Harper \& Row, 1978), hlm. 15.

${ }^{14}$ Ibid., hlm. 23.
} 
transaksi sebagai suatu bentuk kepemimpinan yang berlawanan. Dalam hal ini, Bass menyatakan bahwa seorang pemimpin boleh menunjukkan kedua model kepemimpinan tersebut pada saat memimpin, baik dengan model kepemimpinan transformatif maupun kepemimpinan transaksi. ${ }^{15}$

\section{Gambaran Umum Penerapan Pembelajaran Konstekstual Matematika pada Siswa Kelas IX MTS N II Mejobo}

Gambaran umum penerapan pembelajaran kontekstual matematika pada siswa kelas IX MTS N II Mejobo adalah sebagaimana yang disebutkan Nurhadi dkk (2004) dalam aplikasi tujuh komponen pembelajaran kontekstual matematika yaitu sebagai berikut:

\section{a. Konstruktivisme}

Guru harus yakin bahwa pengetahuan yang tumbuh dan berkembang pada siswa adalah melalui pengalaman dan pemahamannya. Pemahaman berkembang semakin dalam dan semakin kuat apabila guru selalu aktif mengujinya dengan pengalaman baru. Pada umumnya guru sudah menetapkan filosofi ini dalam pembelajaran sehari hari yaitu ketika merancang pembelajaran matematika dalam bentuk siswa bekerja, praktek mengerjakan sesuatu, berlatih secara fisik, menulis, mendemonstrasikan, menciptakan ide dan sebagainya. Dalam hal ini, seorang guru harus menyiapkan perangkat pembelajaran berupa RPP (Rencana Pelaksanaan Pembelajaran) yang telah disesuaikan dengan Satuan Acara Pembelajaran (SAP) dan Silabus Matematika.

\section{b. Menemukan}

Langkah-langkah kegiatan menemukan dalam pembelajaran matematika adalah:

\footnotetext{
${ }^{15}$ Bass, B.M. dan Avolio, B. J, Improving Organizational Effectiveness Through Transformational Leadership (Thousand Oaks, CA: Sage, 1994), hlm. 12.
} 
1) Merumuskan masalah

misal: Bagaimana cara menentukan jarak tempuh roda pada materi lingkaran ?, bagaimana cara menghitung laba dan rugi pada materi aritmatika sosial ?

2) Mengamati atau melakukan observasi

Missal: mencari sumber bacaan yang bisa dijadikan sebagai rujukan berupa buku paket matematika. Mengamati perputaran roda. Mengamati laporan keuangan dalam operasional bisnis.

3) Menganalisis dan menyajikan hasil dalam tulisan, gambar, laporan, bagan, table dan karya lainnya, missal: siswa membuat laporan hasil penghitungan berupa angka di dukung oleh gambar dan table.

4) Mengkomunikasikan atau menyajikan hasil karya pada pembaca, teman sekelas, guru atau audiens yang lain, missal: murid diminta untk mempresentasikan hasil penghitungan di depan guru dan teman-temannya baik dalam bentuk power point maupun jenis laporan lainnya.

c. Bertanya

Dipandang sebagai kegiatan guru untuk mendorong, membimbing, dan menilai kemampuan berfikir siswa. Bagi siswa berguna untuk menggali informasi. Hampir pada semua aktifitas belajar, metode bertanya dapat diterapkan. Hal ini bisa diterapkan dengan cara membuat pertanyaan tingkat tinggi agar siswa berfikir kritis dan mencari pemecahan masalahnya

\section{d. Masyarakat Belajar}

Dalam kelas, guru disarankan selalu melaksanakan pembelajaran dalam kelompok-kelompok. Masyarakat belajar bisa terjadi apabila ada komunikasi dua arah. Seorang guru yang mengajar siswanya bukan contoh masyarakat belajar, karena hanya terjadi komunikasi satu arah. Seseorang terlibat dalam kegiatan belajar memberikan informasi yang 
diberikan oleh teman bicaranya dan sekaligus juga meminta informasi yang diperlukan dari teman belajarnya.

Praktek dalam pembelajaran matematika bisa terwujud dengan cara:

1. Pembentukan kelompok diskusi

2. Mendatangkan para praktisi di kelas

3. Bekerja sama dengan kelas lain yang sederajat

4. Bekerja kelompok dengan kelas diatasnya

5. Bekerja dengan masyarakat

\section{e. Pemodelan}

Contoh praktek pemodelan dalam pembelajaran matematika di kelas adalah:

1. Siswa praktek menghitung garis tengah sepeda masingmasing dengan metode menghitung lingkaran

2. Siswa praktek sebagai penjual jajan yang menghitung laba rugi

\section{f. Refleksi}

Refleksi merupakan respon terhadap kejadian atau pengetahuan yang baru terima, misal ketika pelajaran berakhir siswa diajak meng-evaluasi terhadap hasil belajarnya.

\section{g. Penilaian Yang Sebenarnya}

Kemajuan belajar bisa dinilai dari proses dan bukan melalui hasil. Ketika guru mengajar sepak bola, sisiwa yang tendangannya paling bagus, dialah yang nilainya paling tinggi.

\section{Peran Pembelajaran Kontekstual Dalam Membangkitkan Kepemimpinan Transformatif dan Kreatifitas Berfikir Siswa}

Setiap individu yang hidup di era globalisasi harus mampu mengembangkan kapasitasnya secara optimal, kreatif, produktif dan bisa mengadaptasikan diri ke dalam situasi global yang sangat 
variatif dan cepat berubah. Setiap individu harus mempunyai bekal berupa daya nalar kreatif dan kepribadian yang tidak sekedar simpel melainkan kompleks. Untuk itu keterampilan yang harus dimiliki adalah meliputi keterampilan intelektual, sosial maupun personal.

Pendidikan sebagai bagian integral kehidupan masyarakat di era globalisasi harus dapat memfasilitasi bagi tumbuh dan berkembangnya keterampilan intelektual, sosial dan personal. Pendidikan harus bisa menumbuhkan berbagai kompetensi peserta didik. keterampilan intelektual, sosial dan personal yang di bangun tidak hanya berlandaskan rasio dan logika saja, tetapi juga inspirasi, kreatifitas, moral, intuisi dan spiritual. Sebagaimana pembelajaran matematika di sekolah yang merupakan salah satu pilar penting pendidikan, harus dikembangkan melalui modelmodel pembelajaran yang sesuai dengan tuntutan kebutuhan di era global. Oleh karena itu, model pembelajaran matematika harus menjadi model pembelajaran aktif, inovatif, kreatif, efektif dan menyenangkan (PAIKEM). Model PAIKEM merupakan model pembelajaran konstruktivistik yang beraksentuasi pada learning to know, learning to do, learning to be, dan learning to live together.

Kata "produktif" sering dikaitkan dengan besarnya kapasitas yang dihasilkan suatu perusahaan, baik dari segi jumlah barang, maupun banyaknya jasa yang ditawarkan. Tetapi produktif dalam hal ini adalah kemampuan pribadi, yang dihasilkan seseorang (siswa) dalam menghasilkan suatu karya yang bermanfaat bagi diri sendiri maupun orang lain. Seseorang dikatakan produktif apabila mampu membangkitkan proses berfikir dan kinerja yang dihasilkannya maksimal. Jika seseorang ingin eksis dan maju maka proses berfikirnya harus benar, cepat dan tepat, yaitu proses berfikir yang didahului dari pemahaman terhadap fakta dan selalu dikaitkan dengan Islam sebagai landasan berfikirnya. Mengapa demikian? karena Islam mewajibkan setiap Mukallaf (orang yang terkena beban hukum) untuk selalu berpikir. 
Dalam hal ini, Imam Syafi'i berkata: "Ketahuilah bahwa kewajiban pertama bagi seorang mukallaf adalah berfikir dan mencari dalil untuk ma'rifat kepada Allah Ta'ala". Arti berfikir adalah melakukan penalaran dan perenungan kalbu dalam kondisi orang yang berfikir tersebut dituntut untuk ma'rifat kepada Allah SWT. Dengan berfikir, maka seseorang mampu mencapai ma'rifat terhadap hal-hal yang ghaib berdasarkan hasil pengamatannya dengan indra, dan ini merupakan suatu keharusan dan kebaikan. ${ }^{16}$

Dalam ayat Al-Qur'an disebutkan bahwa: "Berlomba-lombalah kalian dalam hal mengerjakan kebaikan" (QS Al Baqarah: 148). Ayat tersebut menyiratkan bahwa setiap orang yang melakukan kebaikan secara otomotis akan menambah nilai keimanannya. Setiap muslim juga mempunyai kewajiban mendorong muslim lainnya untuk menjadi pribadi yang berilmu dan lebih produktif. Hal ini karena Allah SWT sangat memuliakan orang-orang yang menuntut ilmu dan mengamalkannya pada derajat yang lebih tinggi daripada orang yang tidak ber-ilmu. Sebagaimana Firman Allah dalam QS. Mujadalah: 11 :

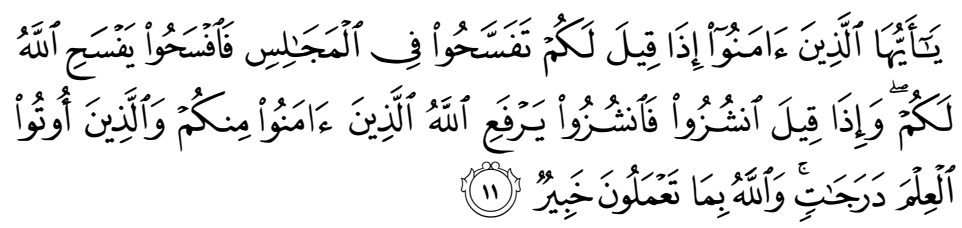

"Hai orang-orang beriman apabila kamu dikatakan kepadamu: "Berlapanglapanglah dalam majlis", Maka lapangkanlah, niscaya Allah akan memberi kelapangan untukmu. dan apabila dikatakan: "Berdirilah kamu”, Maka berdirilah, niscaya Allah akan meninggikan orang-orang yang beriman di antaramu dan orang-orang yang diberi ilmu pengetabuan beberapa derajat. dan Allah Maha mengetabui apa yang kamu kerjakan". (QS. Mujadalah: 11)

Islam adalah agama yang sangat menekankan aspek amal dan etos kerja positif. Orang yang produktif berarti bisa memberikan pengaruh besar bagi kemajuan dan perkembangan

${ }^{16}$ Fiqhul Akbar, Imam Syafi'I, hlm., 16. 
jaman. Berpikir dan melakukan berbagai tindakan produktif menjadi salah satu sarana untuk menundukkan kekuatan alam dan memanfaatkannya sebaik mungkin demi kesejahteraan umat. Dengan dasar inilah maka setiap orang wajib memiliki jiwa kepemimpinan transformatif dan berfikir kreatif, tidak terkecuali pula dengan siswa pembelajar.

\section{Simpulan}

Ketika siswa sudah memasuki usia akil baligh, maka dia terkena beban hukum yang sama untuk melaksanakan hukum Islam secara penuh, memiliki jiwa kepemimpinan transformatif dan berfikir kreatif. Tetapi ironisnya, fakta empiris menunjukkan bahwa sebagian dari siswa di indonesia justru menunjukkan tidak produktif dan tidak memiliki kepemimpinan berfikir. Hal ini dibuktikan dengan data-data yang menunjukkan tentang jumlah kenakalan remaja, misal: remaja yang terjerumus kedalam narkoba, minum-minuman keras, pergaulan bebas, aborsi karena hamil diluar nikah, bunuh diri dan lain-lain yang semakin hari semakin meningkat tajam. ${ }^{17}$ Jika kita melihat secara ekonomi, tidak jarang dari mereka berasal dari keluarga yang mampu dan kaya. Secara pendidikan mereka juga lahir dari orang tua yang berpendidikan tinggi. Secara sosial mereka berada di lingkungan yang super ketat. Mayoritas masyarakat juga beragama Islam. Lalu mengapa kenakalan remaja atau siswa masih sering terjadi?, Mengapa jumlah mata pelajaran yang banyak kurang berpengaruh pada pembentukan pola pikir dan pola sikap yang baik pada siswa? Dan beberapa pertanyaan sejenispun bermunculan.

Salah satu upaya untuk mengatasi hal tersebut adalah dengan menanamkan pada siswa kepribadian Islami, memiliki jiwa kepemimpinan transformative dan berfikir kreatif, agar ketika mereka dihadapkan pada berbagai problema kehidupan, senantiasa menyelesaikannya sesuai dengan aturan Islam dan dapat dipertanggunggjawabkan kepada sang Khaliq. Pola pikir

17 "Pergaulan bebas" dalam Merdeka.com,. 
dan pola sikap Islami ini harus ditanamkan pada siswa, sejak dari pendidikan dasar, menengah, atas hingga perguruan tinggi, baik di lingkungan sekolah, keluarga maupun masyarakat.

Pada saat mereka dilingkungan sekolah, guru (pendidik) memiliki potensi yang sangat besar untuk mengarahkan dan membimbing siswa baik di dalam maupun di luar kelas. Pendekatan yang dilakukan bisa dengan berbagai metode, diantaranya dengan metode pembelajaran matematika kontekstual. Metode ini hanyalah satu dari sekian metode dalam mata pelajaran matematika yang bisa digunakan untuk membangkitkan jiwa kepemimpinan dan kreatifitas berfikir siswa. Hal ini sejalan dengan kebijakan pemerintah yang tertuang dalam Visi Pendidikan Nasional yaitu: "Terwujudnya system pendidikan sebagai pranata sosial yang kuat dan berwibawa untuk memberdayakan semua warga negara Indonesia berkembang menjadi manusia yang berkualitas sehingga mmapu dan proaktif menjawab tantangan zaman yang selalu berubab".

Oleh karena itu setiap materi yang diberikan oleh guru sebisa mungkin harus bisa diaplikasikan dalam kehidupan, agar terjadi pemahaman yang sempurna pada diri siswa. Dalam analisis ini membuktikan bahwa metode pembelajaran kontekstual mampu melibatkan aspek-aspek penting pada diri siswa, baik aspek afektif, kognitif maupun psikomotoriknya melalui tema yang dipelajarinya dan pengalaman secara langsung. 


\section{DAFTAR PUSTAKA}

Arikunto, Penelitian Tindakan Kelas, Jakarta: Bumi Aksara, 2010.

B. Johnson, Elaine, Contextual Teaching dan Learning, Terj, Ibnu Setiawan, Bandung: MLC, 2006.

Bass, B.M. dan Avolio, B. J, Improving Organizational Effectiveness Through Transformational Leadership, Thousand Oaks, CA: Sage, 1994.

Burns, J.M, Leadership, New York: Harper \& Row, 1978.

Departemen Pendidikan Nasional, Rencana Strategis Departemen Pendidikan Nasional, Jakarta: Departemen Pendidikan Nasional, 2007.

Depdiknas, Manajemen Peningkatan Mutu Berbasis Sekolab: Pembelajaran dan Pengajaran Konstektual, Jakarta: Dikdasmen, 2002.

Kotter, J, A force for change: How leadership differs from management, New York Press.,1990.

Negoro, ST dan Harahap, B, Ensiklopedia Matematika, Jakarta: Ghalia Indonesia, 1999.

Nurhadi, Pendekatan Konstekstual (Contextual Teaching dan Learning), Jakarta: Departemen Pendidikan Nasional, 2002.

Sanjaya, Wina, Pembelajaran dalam Implementasi Kurikulum Berbasis Kompetensi, Jakarta : Kencana, 2008.

Siswono, Tatag Yuli Eko, Upaya Meningkatkan Kemampuan Berpikir Kreatif Siswa Melalui Pengajuan Masalah dalam Jurnal Pendidikan Matematika dan Sains, FMIPA Universitas Negeri Yogyakarta. Tahun X, No. 1, Juni 2005.

Stogdill, R. M, Handbook of Leadership, New York: The Free Press, 1974.

Widjayakusuma, Muh Karebet, Menuju Kepemimpinan Penub Berkah, dalam Materi Presentasi, 2010. 